\title{
Effect of Personal and Social Responsibility-Based Social-Emotional Learning Program on Emotional Intelligence
}

\author{
Neslihan Arikan ${ }^{1}$ \\ ${ }^{1}$ Faculty of Sport Science, Gazi University, Ankara, Turkey \\ Correspondence: Neslihan Arikan, Emniyet, Abant 1 Caddesi 10/1C D:1d, 06210 Yenimahalle, Ankara, Turkey. \\ E-mail: neslihanarikangazi@gmail.com
}

Received: October 29, 2019

Accepted: February 3, 2020 Online Published: February 26, 2020

doi:10.5539/jel.v9n2p148

URL: https://doi.org/10.5539/jel.v9n2p148

\begin{abstract}
Programs for social-emotional learning implemented in schools are important in terms of improving students' emotional and social skills. In the study, a 16-week program was prepared using the Social-Emotional Learning (SEL) model based on the Personal and Social Responsibility Model (TPSR). The program was implemented in three different school types and the effect of the TPSR-SEL program on the emotional intelligence levels of the students was examined according to the school types. The research group was composed of 162 students in total who study at Anatolian High School $(\mathrm{n}=55)$, Vocational Technical Anatolian High School $(\mathrm{n}=51)$ and Sports High School $(\mathrm{n}=56)$ in Afyon province. In research, pattern with experimental pre-test final-test control group was used. Experiment and control groups were formed in all three-school types. The 16-week TPSR-SEL program was applied to the students in the experimental groups and the current curriculum was applied to the students in the control groups. The Schutte Emotional Intelligence Scale (SEI-S) was used as a data tool. Standard deviation - mean and Two-Way Covariance Analysis (Two-Way ANCOVA) was used for data analysis. As a result of the descriptive statistics, it was determined that there were significant differences between the SEI-S total scores of the experiment and control groups, that there was a significant increase in the final-test total scores of the students in experiment group in all three types of schools, and that the total scores of the control group students remained at the same level. In addition, it was found that the joint effects of participation in the TPSR-SEL program and school type on emotional intelligence scores were significant.
\end{abstract}

Keywords: emotional intelligence, intelligence, physical education, sports

\section{Introduction}

As they are social institutions, schools bring together a large number of students during an important part of the day. Many children come to school by gaining social and emotional skills in their families, while many children come without acquiring them. Children can come to school without gaining skills like self-expression, expressing their wishes and feelings, coping with their intense emotions, anger management, listening, sharing, assistance and cooperation. Thus, unearned social and emotional skills can cause interpersonal conflicts and disputes in the school environment. If people do not gain these skills and competencies in school, they participate in their lives with the deprivation of these skills and competencies. Therefore, the related problems are moved to the business environment and all social relations. In this context, it is seen that it is important for people to develop social and emotional learning skills, behaviors of taking responsibility, and emotional intelligence levels as of a young age.

Responsibility is seen as both a personal trait necessary for success in school and qualification to be gained through school. Individual responsibility is referred to as a duty to deal with or not to deal with someone else or a situation. Social responsibility, on the other hand, includes taking care of ourselves and others, fulfilling our obligations, contributing to the society of which we belong, and building a better world (Lickona, 1992). Social responsibility education aims to make students sensitive to other people's rights, feelings, and needs, while individual responsibility relates education to progress in personal development and development (Hornby \& Wehmeier, 2005).

Teachers believe that their primary basic goal is to educate individuals and socially responsible students who can focus on both personal development and socio-cultural goals (Hellison, 2011). The strength of the Personal and Social Responsibility Model (TPSR), one of the most effective models for the achievement of moral values, is 
that it provides a special and systematic way to integrate developmental steps and affective gains in situations where the teacher wants to focus on affective gains (Walsh, 2008). Students who learn and adopt individual, social and moral values in physical education classes will also transfer the behaviors they develop and mature into other events that are not inherently related to sports (Weiss \& Smith, 2002).

With its large, complex and rich application area, physical education classes are seen to have an important role in preparing school-age youth for moral and social problems, coping with stress, sporting struggle, playing and giving the necessary values for the right way of life (Pringle, 2010). Sports fields are known to provide unlimited opportunities for intervention not only with game environments but also with the environments where exercises and training are conducted, to bring some values to student and sportsperson behaviors and to reveal individual and social responsibility characteristics (Hellison, 2003).

Programs based on the TPSR reveal that students' responsibilities can be improved (Hellison, 2011). In this model, students are encouraged to take responsibility for respecting the rights and feelings of others, to participate and to make good efforts, to guide their own progress and to respect others in every sense. Students are given the opportunity to apply these responsibilities in a physical activity environment. However, for students, the ultimate goal is to transfer these responsibilities or life skills to other environments (Hellison, 2003). TPSR has been implemented in environments like physical education, community programs, and after-school sports programs (Lee \& Choi, 2015; Walsh, Veri, \& Willard, 2015; Wright, Jacobs, Ressler, \& Jung, 2016).

In a number of studies, many social and emotional skills, also called non-cognitive qualities, have been proven to be in a direct positive relationship with the academic process outcomes in front of students, concurrent with their school performance (Farrington et al., 2012). The school creates an ideal environment for promoting the social-emotional and academic development of children by providing direct access to all children and providing them with characteristics like gaining responsibility, receiving necessary education and contributing to society (Zins, Weissberg, Wang, \& Walberg, 2004).

When schools integrate their efforts to encourage children to learn academically, socially and emotionally, they are at the most successful point in the struggle for fulfilling their educational duties (Elias et al., 1997). In this context, a general consensus has been formed that schools contribute to the social and emotional development of children. Schools are social spaces, and learning is a social process too. Students take the learning activities in cooperation with the support of their teachers and their families. At the same time, it is the process of being able to establish and achieve positive goals, to empathize and demonstrate that, to acquire the knowledge, attitudes, and skills necessary to make the right decisions, and to implement all these characteristics effectively (Aidman \& Price, 2018). SEL is based on five interrelated competencies from the cognitive, behavioral and emotional fields: self-awareness, self-management, positive decision-making, relationship skills, and social awareness (Collaborative for Academic, Social, and Emotional Learning [CASEL], 2014).

In order for children to be successful not only in school but also in life, these basic characteristics need to be developed. Those who do not have these skills are less likely to succeed. In this context, SEL interventions in schools improve the school environment and improve the behavioral and academic functioning of the student Osher, Cantor, Berg, Rose, and Steyer (2017) and demonstrate that he has developed his life skills (Camiré, Forneris, Trudel, \& Bernard, 2011; Danish, Forneris, Hodge, \& Heke, 2004; Fraser-Thomas, Côté, \& Deakin, 2008). Researchers argue that teachers need to develop a student-centered learning environment while teaching students SEL competencies (Andrew, Richards, Ivy, Wright, \& Jerri, 2018). In addition, researches in learning areas and education levels have shown that students learn better in supportive environments where they are authorized to make decisions and that they have opportunities to relate and demonstrate (Deci \& Ryan, 2008).

Zins et al. (2004) mentions that SEL has improved in the following areas: Motivation and responsibility in attitudes; participation and work habits in behavior; a positive attitude towards school in performance, working for the strengthening of society, setting high academic motivation and educational goals, better understanding of behavioral outcomes, having a better ability to cope with school stress, a more positive approach to work and learning. Therefore, it is stated that SEL skills which have positive contributions to life should be included in educational programs (Neil, Lendrum, Wigelsworth, \& Afroditi, 2009; Şahin-Baltacı, 2013).

It has been revealed by studies that with concepts like individual-social responsibility and social-emotional learning, student achievement does not only come from external factors but also internal factors affect learning (health, ability, interest, emotional intelligence, etc.) (Sutiani \& Silitonga, 2017). Emotions, which are one of these factors, play an important role in motivating individuals' abilities and improve the learning process in a variety of areas. These emotions express all aspects that are considered an internal factor and depend on the personality of the individual. The presence and measure of emotions present different results among individuals, 
and this is due to the personality of individuals (Hashempour \& Mehrad, 2014). The role of learning-based emotion can fundamentally increase and decrease the measure of emotion (Pekrun, Goetz, Titz, \& Perry, 2002).

Roberts, Schulze, and MacCann (2008) note that emotional state has the potential to affect thinking, noting that students achieve more successful learning and perform much better when they feel safe, happy, or comfortable with the subject. If the students are in a state of extreme excitement and panic, they work carelessly or fast instead of working regularly or carefully. Pekrun (2006) stated that emotions such as anger, anxiety, and sadness have the potential to disperse students' learning efforts by interfering with their ability to participate in existing tasks.

In this context, emotional intelligence serves as the main source of motivation, knowledge, and innovation. Knowing emotional intelligence as the main part of inner emotion supports individuals to recognize various situations and choose items that are appropriate for their lives (Naidoo, 2000). Emotional intelligence is a powerful internal factor that drives behaviors and trends among individuals, but also the ability of individuals to evaluate their tendencies and execute them in various ways (Landy, 2005). Uno (2010) asserts that people with high achievement have emotional intelligence skills due to working in harmony with cognitive skills.

Accordingly, it is suggested that emotional intelligence consists of four main skills related to each other. The first skill is the ability to perceive emotions, capturing the feelings of one's own and others with information derived from facial expression, verbal messages, body language, or similar cues. The second skill requires using emotions, focusing attention, thinking logically, and producing, using, and feeling emotions for proper communication. The third skill is about understanding emotional processes. This skill requires knowing which events are likely to trigger different types of emotions, being able to blend what is needed from complex emotion bundles, understanding how emotions develop over time. The last skill is that individuals can handle their own emotions and deal with emotionally challenging interpersonal situations (Tatar, Tok, \& Saltukoğlu, 2011).

Pool (1997) states that emotional intelligence predicts success in academic achievement, employment, marriage, and physical health. Gross and John (2003) point out in their studies that in order to become an autonomous person, understanding emotions and managing them, sufficient skills are achieved in order to communicate effectively. Trockel et al. (2000) observed that students with high emotional intelligence listen to their emotions, feel good about themselves, accept themselves as they are because of their respect for themselves, and tend to perform well in school. Likewise, Nelson and Low (2006) argued that emotional intelligence is crucial to the student's personal health and school success and that students with emotional intelligence skills are better able to cope with the challenging and complex school environment. Emotional intelligence, therefore, has the ability to benefit not only to enrich students' learning outcomes but also to raise students' life goals.

Methods like punishment, suppression, and modification of behavior to deal with interpersonal conflicts encountered in schools are far from contributing to students' cognitive, social, and emotional development. Instead of focusing on problematic behavior, students are required to gain proficiency in social skills and social values, understanding and managing their own emotions throughout their entire teaching life, starting before school. Schools often offer programs aimed at learning information, i.e., improving students' cognitive skills. While the academic achievements of the students are seriously focused on their emotional and social development, adequate care is not taken. In this study, a program aimed at improving the social-emotional skills of the students was prepared.

On the other hand, it has been reported that it will be more effective to present SEL with special teaching methods like role-playing, peer coaching, conflict resolution, and perspective-taking for evidence-based implementation (Bickmore, 2002; CASEL, 2014; Jones, 2004). Gordon, Jacobs, and Wright (2016) found that BSSM strongly complies with the SEL framework when pedagogical approaches and strategies are applied. In addition, SEL has been stated to be compatible with physical activity and sports, but little work has been done in this area (Ang, Penney, \& Swabey, 2011; Gordon, Jacobs, \& Wright, 2016; Talebzadeh \& Jarfari, 2012). In this study, SEL, which is adapted to a TPSR-based program, was planned to be implemented in physical education and sports courses and focused on the impact of the program on the emotional intelligence levels of the students.

\section{Method}

\subsection{Purpose of the Research}

The aim of this study is to examine the effect of the TPSR-SEL program on the emotional intelligence levels of students in three different school types. In this respect, the following questions were tried to be answered:

1) Is there a significant difference between the pretest and final test scores of the experimental and control groups applied to the TPSR-SEL program regarding the levels of emotional intelligence? 
2) Does the TPSR-SEL program have any effect on the emotional intelligence levels of the students in the school to which it was applied?

\subsection{Research Pattern}

The study looked at the effectiveness of the TPSR-SEL program in improving the emotional intelligence levels of students studying in different types of schools. For this purpose, experimental and control groups of three different types of schools have been established for the implementation of the TPSR-SEL program. In this study, the pattern with the experimental pre-test final-test control group was used. The control group experiences the natural process (Büyüköztürk, 2019) while the experimental group receives the process (a new course material, a different teaching method or an application such as a training program), whose effect on the dependent variable will be tested.

\subsection{Work Group}

A sampling method for the purpose was used in the research (Yıldırım \& Şimşek, 2018). A total of 162 students in the 9th grade studying in Anatolian High School (experiment=28, control=27), Vocational Technical Anatolian High School (VTAS) (experiment=26, control=25) and Sports High School (experiment=28, control=28) affiliated to the Ministry of National Education (MNE) were included in the study in 2018-2019 academic year fall semester, in Afyon Province. In three different schools, classes forming experiment and control groups were chosen by random assignment method. The ages of the students range from 15 to 17 .

In order to determine whether the groups are equivalent in terms of emotional intelligence levels, the pre-test total scores from the Schutte Emotional Intelligence Scale were compared. The students' pre-test total scores from SEI-S were found to be in the range of -1 and +1 with skew and kurtosis coefficients and the normal distribution of the data was observed and the analyses were continued as follows (Tabachnick \& Fidell, 2013). The result of variance equality is shown in Table 1.

Table 1. Variance equality of pre-test total scores for students' emotional intelligence levels (one-way ANOVA)

\begin{tabular}{llllllll}
\hline & Variables & $\mathrm{N}$ & $\overline{\mathrm{X}}$ & $\mathrm{Sd}$ & $\mathrm{df}$ & $\mathrm{F}$ & $\mathrm{p}$ \\
\hline Pre-test & Experiment & 82 & 128.73 & 11.63 & 1 & 3.006 & .085 \\
& Control & 80 & 125.78 & 9.87 & 160 & & \\
& Anatolian High School & 55 & 127.63 & 9.97 & 2 & .299 & .515 \\
& VTAS & 51 & 127.88 & 11.41 & 159 & & \\
& Sports High School & 56 & 126.37 & 11.33 & & & \\
\hline
\end{tabular}

Note. $\mathrm{p}<.05$.

According to Table 1, there was no significant difference in the pre-test scores for the emotional intelligence levels of the students in the experimental and control groups $(\mathrm{F}(1,160)=3.006, \mathrm{p}>.05)$. There was also no significant difference in the pre-test scores for students' emotional intelligence levels according to school types $(\mathrm{F}(2,159)=.299, \mathrm{p}>.05)$. This indicates that students' emotional intelligence levels are equivalent to each other, according to the school type and groups.

\subsection{Data Collection Tool}

The Schutte Emotional Intelligence Scale was used in the research.

Schutte Emotional Intelligence Scale (SEI-S). It was developed by Schutte, Malouff, Hall, Haggerty, Cooper, Golden, and Dornheim (1998) and reorganized as 41 articles by Austin, Saklofske, Huang, and McKenney (2004). The scale is of the quintet Likert type and consists of three sub-dimensions: optimism/mood regulation, utilization of emotions, and appraisal of emotions.

The scale adapted to Turkish by Tatar et al. (2011), was applied to a total of 1743 people between the ages of 1778,1022 women $(58.6 \%)$ and 721 men (41.4\%). For the whole Cronbach-Alpha internal coherence coefficient .82, for its lower dimensions $.75, .39$ and .76 . have been identified. For the whole of the Cronbach-Alpha internal coherence coefficient of the scale applied to a total of 162 students in this study .74. and for its lower dimensions $.59, .35$ and .72 have been identified.

\subsection{Data Collection Process}

The study planned as one day, 16 weeks, 16 courses and 32 hours in total in the Physical Education and Sports course, which is a compulsory course in the curriculum during the fall semester of the 2018-2019 academic year, with the students studying in 9th-grade classes (experiment=82) in three different types of schools in Afyon, 
which are affiliated to the MNE. The contents and sample applications of the sources of Hellison (2011), CASEL (2012) and Zins et al. (2004) were examined for the preparation of lesson plans. At the end of the review, 16 game-oriented courses were prepared based on a collaborative approach that includes all levels and target behaviors of TPSR and SEL.

The research was conducted in three different types of schools. The functioning of all three types of schools is different. Students attending Sports High School attend applied sports classes in half of the weekly course hours, and in the other half, they see academic courses. Anatolian High School is fully academic, meaning it is aimed at cognitive skills and university preparatory courses are available. In VTAS, students receive vocational training mainly for their chosen branches (computers, electricity, chemistry, child development, etc.) along with academic courses). There are academic courses in all three types of schools, but in addition to academic courses at Sports High School and VTAS, there are applied courses where students can develop their emotional, social and psycho-motor abilities.

Voluntary consent forms were distributed for students informed about the study. After the approval forms were collected, SEI-S was applied for the pre-test. The TPSR-SEL program was then applied to students in experimental groups for 16 weeks. The current study has been continued with the students in the control groups. The current teaching programs of experimental studies and control groups were conducted by physical education teachers who were in charge of the schools. Physical education teachers carrying out experimental studies were given seminars about the functioning of the program and necessary documents and materials related to the course contents were provided. After the application, SEI-S was re-applied to the students in the experimental and control groups as a final-test. Experimental applications are given in Table 2.

Table 2. Experimental applications of research

\begin{tabular}{|c|c|c|c|}
\hline Week & Level & Gain & Event \\
\hline 1 & $\begin{array}{l}\text { Respecting the rights and feelings of } \\
\text { others, self-awareness }\end{array}$ & Respecting yourself and others, self-control & $\begin{array}{l}\text { Introduction games } \\
\text { Socializing games }\end{array}$ \\
\hline 2 & $\begin{array}{l}\text { Respecting the rights and feelings of } \\
\text { others, self-awareness }\end{array}$ & $\begin{array}{l}\text { Reassuring each other, finding logical solutions to } \\
\text { problems }\end{array}$ & $\begin{array}{l}\text { Introduction games } \\
\text { Socializing games }\end{array}$ \\
\hline 3 & $\begin{array}{l}\text { Respecting the rights and feelings of } \\
\text { others, self-awareness }\end{array}$ & $\begin{array}{l}\text { Finding logical solutions, trust, cooperation, } \\
\text { self-control }\end{array}$ & Socializing games \\
\hline 4 & $\begin{array}{l}\text { Self-management, respecting the rights } \\
\text { and feelings of others }\end{array}$ & $\begin{array}{l}\text { Goal setting, motivation, controlling emotions, } \\
\text { self-control }\end{array}$ & Volleyball \\
\hline 5 & $\begin{array}{l}\text { Self-management, making } \\
\text { effort/participation }\end{array}$ & $\begin{array}{l}\text { Controlling the feelings of winning and losing, } \\
\text { taking responsibility, making efforts }\end{array}$ & Fitness test \\
\hline 6 & $\begin{array}{l}\text { Self-management, making } \\
\text { effort/participation }\end{array}$ & $\begin{array}{l}\text { Self-regulation, self-responsibility, cooperation, } \\
\text { strategy development }\end{array}$ & Games with a pilates ball \\
\hline 7 & $\begin{array}{l}\text { Responsible decision making, making } \\
\text { effort/participation }\end{array}$ & $\begin{array}{l}\text { Self-motivation, self-confidence and taking } \\
\text { responsibility in taking decisions }\end{array}$ & Kimball \\
\hline 8 & $\begin{array}{l}\text { Responsible decision making, making } \\
\text { effort/participation }\end{array}$ & $\begin{array}{l}\text { Problem-solving, decision making, result } \\
\text { evaluation, participation }\end{array}$ & Frisby \\
\hline 9 & $\begin{array}{l}\text { Responsible decision making, } \\
\text { self-orientation }\end{array}$ & Goal setting, self-development, decision-making & Sportive games \\
\hline 10 & Relationship management, self-orientation & $\begin{array}{l}\text { Relationship building, maintaining a relationship, } \\
\text { goal setting, self-responsibility, focusing }\end{array}$ & Sportive games \\
\hline 11 & Relationship management, self-orientation & $\begin{array}{l}\text { Cooperation, active listening, conflict negotiating, } \\
\text { goal setting }\end{array}$ & Station work \\
\hline 12 & Relationship management, self-orientation & $\begin{array}{l}\text { Relationship building, goal setting, } \\
\text { self-responsibility }\end{array}$ & Fitness test 2 \\
\hline 13 & $\begin{array}{l}\text { Social awareness, leadership/helping each } \\
\text { other }\end{array}$ & $\begin{array}{l}\text { Social awareness, creativity, self-expression, } \\
\text { collaboration, trust-building, trust in the leader }\end{array}$ & $\begin{array}{l}\text { Team games and } \\
\text { trust-building games }\end{array}$ \\
\hline 14 & $\begin{array}{l}\text { Social awareness, leadership/ helping each } \\
\text { other }\end{array}$ & $\begin{array}{l}\text { Cooperation, creative thinking, motivation, } \\
\text { self-expression, empathy }\end{array}$ & Station work \\
\hline 15 & $\begin{array}{l}\text { Social awareness, leadership/ helping each } \\
\text { other }\end{array}$ & Social awareness, strategy development, leadership & Football \\
\hline 16 & $\begin{array}{l}\text { Social awareness, leadership/ helping each } \\
\text { other }\end{array}$ & $\begin{array}{l}\text { Creative thinking, cooperation, self-expression, } \\
\text { leadership, empathy }\end{array}$ & Preparing a dance show \\
\hline
\end{tabular}


Courses were organized according to TPSR sessions. Approximately 5 minutes of close relational time was spent with the students before starting the course. Then 10 minutes of awareness time was created about the subject of the course on that day. Then, physical activities involving the subject of the course were carried out. At the end of the activities, a group meeting was held, and the students' awareness of the subject and topic of that day was tried to be increased and they were Behavioral to express their thoughts. Finally, students were asked to evaluate themselves at the end of each course.

\subsection{Data Analysis}

In the study analysis of the data, standard deviation and mean analysis for descriptive statistics of pre-test and final-test scores obtained from SEI-S; One-way ANOVA analysis for determining variance equality of groups; Two-way Covariance Analysis (Two-way ANCOVA) was used to check the pre-test scores of the groups and determine if there was a differentiation between the final-test scores.

\section{Findings}

The students' pre-test and final test total scores from SEI-S were found to be in the range of -1 and +1 with skew and kurtosis coefficients and the normal distribution of the data was observed and the analyses were continued as follows (Tabachnick \& Fidell, 2013). The Skewness and Kurtosis values are given in Table 3.

Table 3. The Skewness and Kurtosis values of the SEI-S

\begin{tabular}{|c|c|c|c|c|c|c|}
\hline & \multirow[b]{2}{*}{ Variables } & \multirow{2}{*}{$\begin{array}{l}\mathrm{N} \\
\text { Statistic }\end{array}$} & \multicolumn{2}{|l|}{ Skewness } & \multicolumn{2}{|l|}{ Kurtosis } \\
\hline & & & Statistic & Std.Error & Statistic & Std.Error \\
\hline \multirow[t]{2}{*}{ Pretest } & Experiement & 82 & .398 & .266 & -.098 & .526 \\
\hline & Control & 80 & .198 & .269 & -.439 & .532 \\
\hline \multirow[t]{3}{*}{ Posttest } & Experiement & 82 & .500 & .266 & -.624 & .526 \\
\hline & Control & 80 & .351 & .269 & -.273 & .532 \\
\hline & Anatolian High School & 55 & -.212 & .322 & -.203 & .634 \\
\hline \multirow[t]{3}{*}{ Pretest } & VTAS & 51 & .479 & .333 & -.287 & .656 \\
\hline & Sports High School & 56 & .722 & .319 & .446 & .628 \\
\hline & Anatolian High School & 55 & .263 & .322 & -.245 & .634 \\
\hline \multirow[t]{2}{*}{ Posttest } & VTAS & 51 & .187 & .333 & .460 & .656 \\
\hline & Sports High School & 56 & .688 & .319 & -.497 & .628 \\
\hline
\end{tabular}

The mean and standard deviation values of the pretest and posttest scores as the types of schools of the students obtained from SEI-S are given in Table 4. 
Table 4. Mean $(\overline{\mathrm{X}})$ and Standard Deviation $(\mathrm{Sd})$ of SEI-S

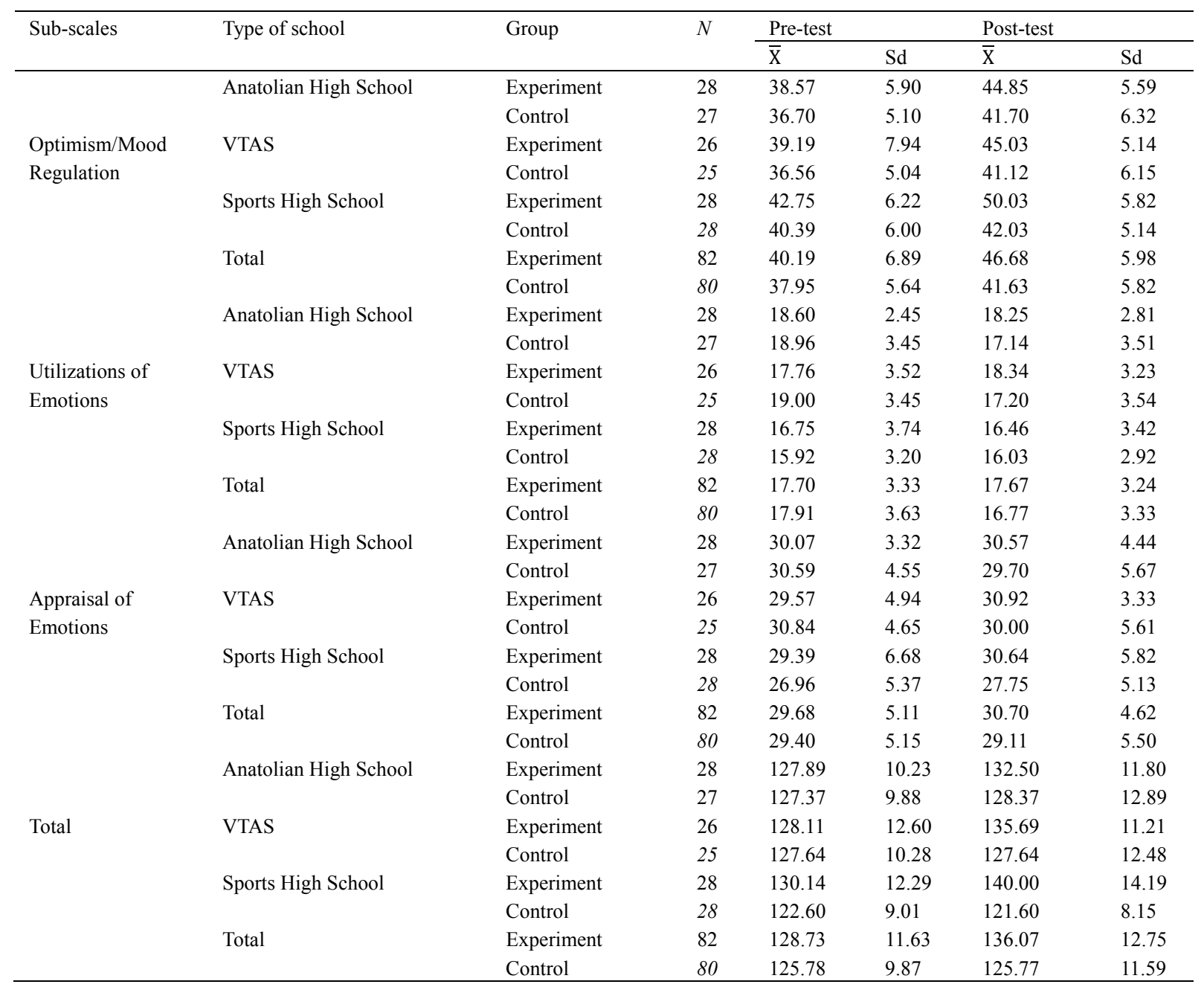

According to the SEI-S final-test total scores, the emotional intelligence levels of the students in the experimental group increased, while the emotional intelligence levels of the students in the control group remained at the same level. When SEI-S is examined according to the lower dimensions, it is observed that there is an increase in the optimism/mood regulation scores of the students in the experiment and control group, a decrease in the scores of the utilizations of emotions, and an increase in the scores of the appraisal of emotions in the experimental group and a decrease in the control group.

Furthermore, when the SEI-S total scores of the experimental groups are examined according to the type of school, it is observed that Anatolian High School score averages have increased from $X=127.89$ to $X=132.50$, VTAS has increased from $X=128.11$ to $X=135.69$, and Sports High School has increased from $X=130.14$ to $X=140.00$. According to the results, the most increase was in the emotional intelligence scores of the students who studied in Sports High Schools.

Two-way ANCOVA analysis was conducted to determine whether there was a significant difference between the final-test scores when the students' pre-test scores were checked by groups and school types. The results of the analysis are given in Table 5 . 
Table 5. Two-way ANCOVA results for SEI-S

\begin{tabular}{lllllll}
\hline Source & Type III Sum of squares & Df & Mean square & F & $\mathrm{p}$ & $\mathrm{n}^{2}$ \\
\hline Covariate (pretest) & 1998.43 & 1 & 1998.43 & 15.290 & $.000^{*}$ & .090 \\
Type of school & 36.91 & 2 & 18.46 & .141 & .868 & .002 \\
Group & 3396.06 & 1 & 3396.06 & 25.983 & $.000^{*}$ & .144 \\
Type of school*group & 1003.78 & 2 & 501.89 & 3.840 & $.024^{*}$ & .047 \\
Error & 20258.84 & 155 & 130.70 & & & \\
Total & 2807658.00 & 162 & & & & \\
Corrected total & 28099.97 & 161 & & & & \\
\hline
\end{tabular}

Note. $\mathrm{p}<.05^{*}$, Dependent variable: posttest.

According to Table 5, when SEI-S pre-test total scores are checked and final test total scores are examined; it was found out that there was no significant difference between the scores of the groups in terms of emotional intelligence levels according to school type $[\mathrm{F}(2,155)=.141, \mathrm{p}>.05]$. According to the Bonferroni test results, a significant difference was found between the final test scores between the experimental group $(\mathrm{X}=135.58)$ and the control group $(X=126.33)$ in favor of the experimental group. Although there was an increase in the emotional intelligence levels of the students in the experimental group, this increase was not statistically significant in terms of school type. According to Kinnear and Gray (1999) classification, in experimental groups $(\mathrm{n} 2=.144)$ and in the common effect between experimental groups and school type (n2=.047) the effect factor on emotional intelligence level is observed to be quite high. In addition, it was found that the joint effects of participation in the TPSR-SEL program and school types on emotional intelligence scores were significant $[\mathrm{F}(2,155)=3.840, \mathrm{p}<.05]$. This indicates that the emotional intelligence levels of the students attending and not attending the TPSR-SEL program vary depending on the type of school they are studying.

\section{Discussion and Conclusion}

In this study, the TPSR-SEL program was applied for 16 weeks to students who studied in three different school types and the effect of the program on the emotional intelligence levels of students according to school types was examined. The results of the study showed that the TPSR-SEL program has a significant effect on the development of emotional intelligence levels of students. In addition, the TPSR-SEL program applied school types were found to be effective in the emotional intelligence levels of the students. This important result suggests that schools should not only limit themselves to cognitive space but also offer programs to improve students' social and emotional skills. Additionally, the study shows that TPSR and SEL are compatible with each other. This result is proof that TPSR-based sports education facilitates SEL in students. Another result of the research is that SEL has positive results in the field of physical education and sports. It provides positive evidence for schools seeking to implement SEL in physical activity and sports classes. The studies carried out support the research result (Ang, Penney, \& Swabey, 2011; Gordon, Jacobs, \& Wright, 2016; Talebzadeh \& Jarfari, 2012).

According to the SEI-S final-test total scores, it was determined that the emotional intelligence levels of the students in the experimental group increased, while the emotional intelligence levels of the students in the control group remained at the same level. Therefore, it can be stated that the TPSR-SEL program has an effect on the development of emotional intelligence levels of students. When SEI-S is examined according to the lower dimensions, it has seen that experimental and control groups developed behaviors like "experience evaluation, finding happy activities, overcoming problems more easily, complimenting people, being optimistic, creating new ideas during emotional changes". However, when the mood changes, there is a decrease in behaviors like seeing new possibilities, affecting the quality of life by emotions, contribution of emotions in generating ideas and solving problems. Therefore, it can be stated that students are unable to control their emotions, shape their lives with their emotions and make decisions. Environments should be created in schools that allow students to experience different emotions and moods and to make the right decisions in the cases, to produce solutions and to demonstrate how they should behave. In addition, at the end of the program, there was an increase in the behaviors of students in experimental groups like understanding non-verbal messages of people, distinguishing that they were serious or joking, communicating with people more easily, establishing close friendships, and decrease in students in control groups. Therefore, it can be stated that the TPSR-SEL program improves students' showing empathy, understanding the feelings of others and communicating comfortably with others.

In addition, the increase in emotional intelligence scores was found to be highest in Sports High School, medium in VTAS, and lowest in Anatolian High School students. The interaction of students with each other and their 
environment is important for their socialization. It is observed that an education system focused solely on academic course success does not adequately increase the social intelligence levels of students. Therefore, the fact that the education given in schools is versatile will improve the cognitive, social, affective and physical characteristics of the students much more. In this context, various and diverse activities should be designed and implemented in schools to improve students' creativity, thinking skills, problem-solving skills, physical abilities, hand skills, etc. According to Gardner (1993), individuals do not have the same way of thinking, and education, if it takes differences seriously, should serve all individuals most effectively. If individuals can recognize different combinations of intelligence, they may be luckier at solving the problems they will face (Davis, Christodoulou, Seider, \& Gardner, 2011).

According to the results of this study, it was found out that there was a significant difference in the emotional intelligence scores of the students in favor of the experimental group. While this difference was not found to be significant by school type, it was found that the common effect on emotional intelligence scores of the experiment group and school type was significant. Therefore, the type of school is effective in changing the emotional intelligence levels of the students participating in the TPSR-SEL program. Only information-oriented, cognitive-level education is given in Anatolian High School In Sports High School and VTAS, students communicate with each other much more, collaborate, carry out team works, having the feelings of being happy, excited, sad by being in an environment of winning and losing in competitions, and experiencing the feeling of accomplishment. In this context, besides the model applied to increase the emotional intelligence levels of the students, these types of schools also contributed.

In this study, only TPSR-SEL program was applied. Different parameters were also examined during the experimental study process, but the study focused solely on the effect of emotional intelligence levels in three different school types of the program. Future studies can be done by making examinations in different model combinations, different age groups and different parameters (self-efficacy, attitude, individual-social responsibility, etc.). Moreover, Physical Education Teachers in schools conducted the model applications, no information on the degree of loyalty to the model has been obtained, and this issue can be taken into consideration in future studies.

\section{Recommendations}

In school types that adopt only an academic success-oriented education approach (such as Anatolian High School, Science High School, Teacher-High School, Social Sciences High School), students should also be offered activities that improve their abilities. In schools, students should be provided with environments where they can interact with nature, society, environment, peers. Activities should be organized in these environments where they will experience behaviors like sharing, helping, empathizing, leading, creating team spirit, winning-losing, problem-solving, and strategy development. In the teaching activities of the school programs, more time should be allocated to social and emotional skills and programs should be prepared that develop these activities outside of the course.

Instead of a direct teaching model in physical education and sports classes in schools, applying different models that enhance social and emotional abilities will make it easier for students to be prepared for life. In order to improve the emotional intelligence levels of the students, it is necessary to reorganize the teaching programs at all levels of education. With these programs, students will be able to gain the ability to understand the feelings of themselves and others, to think sensibly and to produce feelings for the right communication, to control their emotions and to cope with negative emotions, and their emotional intelligence levels will rise. School administrations may be encouraged to use SEL in physical activity and sports. Works can be done with other SEL-compliant models and methods, like TPSR.

\section{References}

Aidman, B., \& Price, P. (2018). Social and emotional learning at the middle level: One school's journey. Middle School Journal, 49(3), 26-35. https://doi.org/10.1080/00940771.2018.1439665

Andrew, K., Richards, R., Ivy, V. N., Wright, P. M., \& Jerri, E. (2018). Teach Social and Emotional Learning in Elementary Physical Education. A Journal for Physical and Sport Educators, 27(2).

Ang, S. C., Penney, D., \& Swabey, K. (2011). Pursuing social and emotional learning outcomes through sport education. In P. Hastie (Ed.), Sports Education: International Perspectives (pp. 116-132).

Austin, E. J., Saklofske, D. H., Huang, S. H. S., \& McKenney, D. (2004). Measurement of Trait Emotional İntelligence: Testing and Cross-Validating a Modified Version of Schutte Et Al.'s (1998) Measure. Personality and Individual Differences, 36(3), 555-562. https://doi.org/10.1016/S0191-8869(03)00114-4 
Bickmore, K. (2002). Peer mediation training and program implementation in elementary schools: Research results. Conflict Resolution Quarterly, 20(2), 137-160. https://doi.org/10.1002/crq.3890200203

Büyüköztürk, Ş. (2019). Manual of Data Analysis for Social Sciences. Statistics, Research Design, Spss Applications and Review (25th ed.). Pegem Akademi. https://doi.org/10.14527/9789756802748

Camiré, M., Forneris, T., Trudel, P., \& Bernard, D. (2011). Strategies for helping coaches facilitate positive youth development through sport. Journal of Sport Psychology in Action, 2(2), 92-99. https://doi.org/10.1080/21520704.2011.584246

CASEL. (2012). 2013 CASEL guide: Effective social and emotional learning programs (Preschool and elementary school edition). Chicago, IL: CASEL

CASEL. (2014). What is social and emotional learning. Retrieved July 10, 2019, from https://casel.squarespace.com/social-and-emotional-learning

Danish, S., Forneris, T., Hodge, K., \& Heke, I. (2004). Enhancing youth development through sport. World Leisure Journal, 46(3), 38-49. https://doi.org/10.1080/04419057.2004.9674365

Davis, K., Christodoulou, J., Seider, S., \& Gardner, H. (2011). The Theory of Multiple Intelligences. In R. J. Sternberg \& S. B. Kaufman (Eds.), Cambridge Handbook of Intelligence (Cha. 24, pp. 485-503). Cambridge University Press. https://doi.org/10.1017/CBO9780511977244.025

Deci, E. L., \& Ryan, R. M. (2008). Self-determination theory: A macro theory of human motivation, development, and health. Canadian Psychology, 49, 182-185. https://doi.org/10.1037/a0012801

Elias, M. J., Zins, J. E., Weissberg, R. P., Frey, K. S., Greenberg, M. T., Haynes, N. M., ... Shriver, T. P. (1997). Promoting social and emotional learning: Guidelines for educators. Alexandria, VA: Association for Supervision and Curriculum Development.

Farrington, C. A., Roderick, M., Allensworth, E., Nagaoka, J., Keyes, T. S., Johnson, D. W., \& Beechum, N. O. (2012). Teaching adolescents to become learners: The role of noncognitive factors in shaping school performance: A Critical Literature Review. Consortium on Chicago School Research.

Fraser-Thomas, J., Côté, J., \& Deakin, J. (2008). Understanding dropout and prolonged engagement in adolescent competitive sport. Psychology of Sport and Exercise, 9(5), 645-662. https://doi.org/10.1016/j.psychsport.2007.08.003

Gardner, H. (1993). Multiple Intelligences. Basic Books; Highlighting edition.

Gordon, B., Jacobs, J., \& Wright, P. M. (2016). Social and emotional learning through a Teaching Personal and Social Responsibility based after-school program for disengaged middle-school boys. Journal of Teaching in Physical Education, 35(4), 358-369. https://doi.org/10.1123/jtpe.2016-0106

Gross, J. J., \& John, O. P. (2003). Individual differences in two emotion regulation processes: Implications for affect, relationships, and well-being. Journal of Personality and Social Psychology, 85(2), 348-362. https://doi.org/10.1037/0022-3514.85.2.348

Hashempour, S., \& Mehrad, A. (2014). The Effect of Anxiety and Emotional Intelligence on Students' Learning Process. Journal of Education \& Social Policy, 1(2).

Hellison, D. R. (2011). Teaching Personal and Social Responsibility through Physical Activity. Champaign, IL: Human Kinetics.

Hellison, D. R. (2003). Teaching responsibility through physical activity (2nd ed.). Champaign, IL: Human Kinetics.

Hornby, A. S., \& Wehmeier, S. (Eds.). (2005). Oxford advanced learner's dictionary of current English (7th ed.). Oxford, UK: Oxford University Press.

Jones, T. (2004). Conflict resolution education: The field, the findings, and the future. Conflict Resolution Quarterly, 22(1-2), 973-986. https://doi.org/10.1002/crq.100

Kinnear, R., \& Grey, C. (1999). SPSS for Windows Made Simple. New York, NY: Psychology Press, Hove.

Landy, F. J. (2005). Some historical and scientific issues related to research on emotional intelligence. Journal of Organizational Behavior, 26, 411-424. https://doi.org/10.1002/job.317

Lee, O., \& Choi, E. (2015). The influence of professional development on teacher's implementation of the Teaching Personal and Social Responsibility model. Journal of Teaching in Physical Education, 34(4). 
https://doi.org/10.1123/jtpe.2013-0223

Lickona, T. (1992). Educating for a character. New York: Bantam Books.

Naidoo, A. V. (2000). Community Psychology: Constructing Community, Reconstructing Psychology in South Africa. Inaugural Address: Please Reference as Follows: University of Stellenbosch.

Neil, H., Lendrum, A., Wigelsworth, M., \& Afroditi, K. (2009). Implementation of Primary Social and Emotional Aspects of Learning small group work: A qualitative study. Pastoral Care in Education, 27(3), 219-239. https://doi.org/10.1080/02643940903136808

Nelson, D., \& Low, G. (2006). Emotional intelligence and college success: A research-based assessment and intervention model. In J. Cassidy, A. Martinez \& C. Swift (Eds.), Supporting Student Success (pp. 236247).

Osher, D., Cantor, P., Berg, J., Rose, T., \& Steyer, L. (2017). The Science of learning and development. Washington, DC: American Institutes for Research, Turnaround for Children, The Opportunity Institute, The Learning Policy Institutes, Education Counsel.

Pekrun, R. (2006). The Control-Value Theory of Achievement Emotions: Assumptions, Corollaries, and Implications for Educational Research and Practice. Educational Psychology Review, 18, 315-341. https://doi.org/10.1007/s10648-006-9029-9

Pekrun, R., Goetz, T., Titz, W., \& Perry, R. P. (2002). Academic Emotions in Students' Self-Regulated Learning and Achievement: A Program of Qualitative and Quantitative Research. Educational Psychologist, 37(2), 91-105. https://doi.org/10.1207/S15326985EP3702_4

Pool, C. R. (1997). Up with Emotional Health. Educational Leadership. Reports, 54(8), 12-14.

Pringle, R. (2010). Finding pleasure in physical education: A critical examination of the educative value of positive movement affects. Quest, 62, 119-134. https://doi.org/10.1080/00336297.2010.10483637

Roberts, R. D., Schulze, R., \& MacCann C., (2008). The measurement of emotional intelligence: A decade of progress? In The SAGE handbook of personality theory and assessment (Vol. 2: Personality measurement and testing, pp. 461-482). Thousand Oaks, CA, US: Sage Publications, Inc. https://doi.org/10.4135/9781849200479.n22

Şahin-Baltacı, H. (2013). Turkish 6th-8th Grade Students' Social-Emotional Learning Skills and Life Satisfaction. International Journal on New Trends in Education and Their Implications, 4(2), 1-14.

Schutte, N. S., Malouff, J. M., Hall, L. E., Haggerty, D. J., Cooper, J. T., Golden, C. J., et al. (1998). Development and validation of a measure of emotional intelligence. Pers Indiv Differ, 25(2), 167-177. https://doi.org/10.1037/t06718-000

Sutiani, A., \& Silitonga, M. Y. (2017). The Effect of Learning Models and Emotional Intelligence on Students Learning Outcomes on Reaction Rate. Cite as: AIP Conference Proceedings 1868, 030011. https://doi.org/10.1063/1.4995110

Tabachnick, B., \& Fidell, L. (2013). Using Multivariate Statistics (6th International edition cover). New Jersey: Sage Publications, Thousand Oaks.

Talebzadeh, F., \& Jarfari, P. (2012). How sport and art can be effective in the fields of social, cognitive and emotional learning. Procedia-Social and Behavioral Sciences, 47, 891-903. https://doi.org/10.1016/j.sbspro.2012.06.871

Tatar, A., Tok, S., \& Saltukoğlu, G. (2011). The Adaptation of the Revised Schutte Emotional Intelligence Scale into Turkish and Investigation of Psychometric Properties. Bulletin of Clinical Psychopharmacology, 21(4), 325-338. https://doi.org/10.5455/bcp.20110624015920

Trockel, M. T., Egget, D. L., \& Barnes, M. D. (2000). Health-Related Variables and Academic Performance Among First-Year College Students: Implications for Sleep and Other Behaviors. Journal of American College Health, 49(3), 125-131. https://doi.org/10.1080/07448480009596294

Uno, H. (2010). New Oriental in Psychology of Learning. Earth Literacy: Jakarta.

Walsh, D. (2008). Helping youth in underserved communities envision possible futures: An extension of the teaching personal and social responsibility model. Research Quarterly for Exercise and Sport, 79, 209-221. https://doi.org/10.1080/02701367.2008.10599484

Walsh, D., Veri, M., \& Willard, J. (2015). Kinesiology career club: Undergraduate student mentors' perspectives 
on a physical activity-based Teaching Personal and Social Responsibility program. Physical Educator, 72(2), 3017.

Weiss, M. R., \& Smith, A. L. (2002). Moral development in sport and physical activity: Theory, research, and intervention. In T. S. Horn (Ed.), Advances in sport psychology inside (2nd ed., pp. 243-280). Champaign, IL: Human Kinetics.

Wright, P., Jacobs, J., Ressler, J. D., \& Jung, J. (2016). Teaching for a transformative educational experience in a sport for development program. Sport, Education, and Society, 21(4), 531-548. https://doi.org/10.1080/13573322.2016.1142433

Yıldırım, A., \& Şimşek, H. (2018). Qualitative Research Methods. Ankara: Seçkin Yayıncılık.

Zins, J. E., Weissberg, R., Wang, M. C., \& Walberg, H. J. (2004). Building academic success on social and emotional learning: What does the research say? New York: Columbia University Teachers College Press.

\section{Copyrights}

Copyright for this article is retained by the author, with first publication rights granted to the journal.

This is an open-access article distributed under the terms and conditions of the Creative Commons Attribution license (http://creativecommons.org/licenses/by/4.0/). 